\title{
Efficient Cleaning of Steel Instruments in an Otolaryngology Outpatient Clinic
}

\author{
Kohichiro Shigeno
}

\begin{abstract}
We examined efficient cleaning methods for steel instruments, i.e., aural speculum, nasal speculum, tongue depressor and forceps, and whether the use of any of these methods could skip cleaning instruments by hand at an otolaryngology outpatient clinic. The steel instruments that were used in the outpatient area and instruments contaminated with blood were cleaned either by hand, dipping in detergent, in a desk top washer-disinfector, or using an ultrasonic device. Before and after the cleaning, the remaining protein was measured by the Coomassie brilliant blue method. There were no significant differences in the residual amount of protein among the cleaning methods. The amount of residual protein was up to 60 $\mu \mathrm{g}$ per instrument. Except for those cleaned by hand, the amount of residual protein was below $30 \mu \mathrm{g}$ per instrument for more than $90 \%$ of the instruments. Thus, steel instruments used at an otolaryngology outpatient clinic can be washed effectively by dipping them in detergent containing an enzyme cleaner, with no need for cleaning by hand. Instruments contaminated with blood can be expected to be cleaned securely and safely by both dipping in detergent containing an enzyme cleaner and ultrasonic cleaning.
\end{abstract}

Keywords : steel instrument, outpatient clinic, cleaning by hand, dipping in detergent, ultrasonic cleaning

\section{References}

1) 小林寛伊, 大久保憲, 尾家重治 : 新版消毒と滅菌のガイド ライン (小林寛伊編)。8-43 頁，へるす出版，東京， 2011.

2) 満田年宏: 医療施設における消毒と滅菌のための CDC ガイ ドライン 2008. 1-216 頁，ヴァンメディカル，東京， 2009.

3) Vickery K, Pajkos A and Cossart Y : Removal of biofilm from endoscopes: evaluation of detergent efficiency. Am J Infect Control 32: 170-176, 2004.

4）伏見 了, 花村 亮, 中田精三, 他：一次消毒された污染 物の洗浄障害について. 医器学 73: 281-289, 2003.
5）小林寛伊，永井 勲，大久保憲，他：鋼製小物の洗浄ガイ ドライン 2004 I. 使用済み鋼製小物の一次洗浄／消毒廃 止に向けて. 医器学 75: 396-399, 2005.

6）一般社団法人日本医療機器学会 : 洗浄評価判定ガイドライ ン. 1-15 頁, 2012. http://www.jsmi.gr.jp/senjyou.pdf

7) 伏見了, 島崎 豊, 吉田葉子: 再使用器材の洗浄. 洗浄 · 消毒・滅菌の基本と具体策. 40 頁, ヴァンメディカル, 東 京, 2008 .

8）伏見了, 野口悟司, 船越文男, 他: 酵素洗剤中プロテアー ゼ活性の保存安定性および洗浄時温度と洗浄力の関係に関 する研究. 医器学 70: 648-651, 2000. 
The amount of protein attached to steel instruments used in the outpatient area before cleaning and instruments that were artificially contaminated with blood before cleaning

\begin{tabular}{|c|c|c|c|c|}
\hline & aural speculum & forceps & tongue depressor & nasal speculum \\
\hline \multicolumn{5}{|c|}{ Steel instruments that were used in the outpatient area } \\
\hline Number of steel instruments & 6 & 6 & 6 & 6 \\
\hline Amount of protein ( $\mu \mathrm{g} /$ instrument, Mean $\pm \mathrm{SD})$ & $64.9 \pm 26.3$ & $61.3 \pm 24.4$ & 83. $7 \pm 31.3$ & $66.5 \pm 20.4$ \\
\hline Range ( $\mu \mathrm{g} /$ instrument) & 20 and under-92. 4 & 29. $7-97.4$ & 52. $3-126.9$ & 51. $0-103.9$ \\
\hline \multicolumn{5}{|c|}{ Steel instruments that were artficially contaminated with blood } \\
\hline Number of steel instruments & 6 & 6 & 6 & 6 \\
\hline Amount of protein ( $\mu \mathrm{g} /$ instrument, Mean $\pm \mathrm{SD})$ & 5626. $4 \pm 1158.7$ & 2496. $1 \pm 977.9$ & $6089.5 \pm 2356.3$ & $6445.1 \pm 1722.0$ \\
\hline Range ( $\mu \mathrm{g} /$ instrument $)$ & 4328. 9-7419. 4 & 1612. 9-3936. 0 & 3387.1-9806.9 & 3836. 0-9112.9 \\
\hline
\end{tabular}

The residual amount of protein on steel instruments used in the outpatient area after the various cleaning methods (number of instruments (\%))

\begin{tabular}{|c|c|c|c|c|c|c|}
\hline $\begin{array}{l}\text { Amount of residual } \\
\text { protein } \\
(\mu \mathrm{g} / \text { instrument }) \\
(\mathrm{n}=24)\end{array}$ & $\begin{array}{l}\text { Cleaning by } \\
\text { hand }\end{array}$ & $\begin{array}{c}\text { Cleaning by hand } \\
+ \\
\text { Ultrasonic cleaning }\end{array}$ & $\begin{array}{l}\text { Dipping in } \\
\text { detergent } \\
\text { (20 minutes) }\end{array}$ & $\begin{array}{c}\text { Dipping in detergent } \\
(10 \text { minutes }) \\
+ \\
\text { Ultrasonic cleaning }\end{array}$ & WD-32R ${ }^{\circledR}$ & $\begin{array}{c}\text { WD-32R }{ }^{\circledR} \\
+ \\
\text { Ultrasonic cleaning }\end{array}$ \\
\hline 20 and under & $14(58 \%)$ & $18(75 \%)$ & $16(67 \%)$ & $15(63 \%)$ & $20(83 \%)$ & $19(79 \%)$ \\
\hline $21-30$ & $6(25 \%)$ & $6(25 \%)$ & $7(29 \%)$ & $7(29 \%)$ & $3(13 \%)$ & $3(13 \%)$ \\
\hline $31-40$ & 0 & 0 & $1(4 \%)$ & $1(4 \%)$ & 0 & 0 \\
\hline $41-50$ & $2(8 \%)$ & 0 & 0 & 0 & 0 & $1(4 \%)$ \\
\hline $51-60$ & $2(8 \%)$ & 0 & 0 & $1(4 \%)$ & $1(4 \%)$ & $1(4 \%)$ \\
\hline
\end{tabular}

Cleaning by hand: brush cleaning in a neutral detergent at room temperature for about 10 seconds per instrument. Dipping in detergent: dipping in a neutral detergent containing an enzyme cleaner at about $40^{\circ} \mathrm{C}$. Ultrasonic cleaning: a desktop washer that cleans automatically in a neutral detergent for 10 minutes. WD-32R ${ }^{\circledR}$ : a desktop washer-disinfector that cleans automatically in an alkaline detergent for 36 minutes. There were no significant differences in the residual amounts of protein among the cleaning methods.

The residual amount of protein on steel instruments artificially contaminated with blood after the two cleaning methods (number of instruments $(\%))$

\begin{tabular}{ccc}
\hline \hline $\begin{array}{c}\text { Amount of residual protein } \\
(\mu \mathrm{g} / \text { instrument })\end{array}$ & $\begin{array}{c}\text { Dipping in detergent }(20 \text { minutes }) \\
(\mathrm{n}=24)\end{array}$ & $\begin{array}{c}\text { Dipping in detergent }(10 \text { minutes })+ \\
\text { Ultrasonic cleaning }(\mathrm{n}=23)\end{array}$ \\
\hline 20 and under & $12(50 \%)$ & $18(78 \%)$ \\
$21-30$ & $3(13 \%)$ & $2(9 \%)$ \\
$31-40$ & $1(4 \%)$ & $1(4 \%)$ \\
$41-50$ & $3(13 \%)$ & $2(9 \%)$ \\
$51-60$ & 0 & 0 \\
$61-70$ & $1(4 \%)$ & 0 \\
$71-80$ & $1(4 \%)$ & 0 \\
$81-90$ & $3(13 \%)$ & 0
\end{tabular}

Both cleaning methods reduced the amount of residual protein below $100 \mu \mathrm{g}$ per instrument. However, the residual amount of protein after both dipping in detergent and ultrasonic cleaning was significantly lower than that after only dipping in detergent $(p=0.01)$. 